\title{
Nuclear Factor of Activated T-Cells, Cytoplasmic 3
}

National Cancer Institute

\section{Source}

National Cancer Institute. Nuclear Factor of Activated T-Cells, Cytoplasmic 3. NCI

Thesaurus. Code C93151.

Nuclear factor of activated T-cells, cytoplasmic 3 (1075 aa, $116 \mathrm{kDa}$ ) is encoded by the human NFAT C3 gene. This protein plays a role in the modulation of transcription. 